\title{
INFLUENCE OF PLANT SPACING ON THE GROWTH AND YIELD OF TOMATO (Lycopersicon esculentum Mill.) VARIETIES
}

\author{
*Falodun, E. J. and Emede, T. O. \\ Department of Crop Science, Faculty of Agriculture, University of Benin, Nigeria \\ *Corresponding author: ehizogie.falodun@uniben.edu
}

\begin{abstract}
Field studies on the effect of plant spacing on three varieties of tomato (Lycopersicon esculentum Mill.) was carried out at the Experimental Farm of the Department of Crop Science, Faculty of Agriculture, University of Benin, Benin City. Three varieties of tomato and three spacing regimes were used. The experiments were laid out in $3 \times 3$ factorial combination in a randomized complete block design (RCBD) in three replications. The treatments had three varieties of tomato (Roma savanna, UC 82, and Roma VF) and three plant spacing regimes $(75 \mathrm{~cm} \times 40 \mathrm{~cm}, 75 \mathrm{~cm} \times 50 \mathrm{~cm}$, and $75 \mathrm{~cm} \times 60 \mathrm{~cm})$. The results obtained showed that the effect of variety on the vegetative characters was significant $(p \leq 0.05)$ but did not follow a particular order. The narrowest spacing of 75 $\mathrm{cm} \times 40 \mathrm{~cm}$ showed superiority in plant height and leaf area compared with the wider plant spacing of $75 \mathrm{~cm} \times 50 \mathrm{~cm}$ and $75 \mathrm{~cm} \times 60 \mathrm{~cm}$. Roma savanna attained $50 \%$ flowering earlier and had the highest number of fruits per plant (10.01) and fruit yield (10.87 t/ha) compared with UC 82 (6.73 and 8.73 t/ha) and Roma VF varieties ( 7.66 and $8.28 \mathrm{t} / \mathrm{ha}$ ). Significant yield differences were recorded in tomato plants spaced at $75 \mathrm{~cm} \mathrm{x}$ $40 \mathrm{~cm}$ and $75 \mathrm{~cm} \times 50 \mathrm{~cm}$ which produced statistically similar fruit yield of (10.41 t/ha) and ( $9.76 \mathrm{t} / \mathrm{ha}$ ) respectively above the yield of $(7.72 \mathrm{t} / \mathrm{ha})$ obtained from plants spaced at $75 \mathrm{~cm} \times 60 \mathrm{~cm}$.
\end{abstract}

Keywords: Flowering, plants, Roma savanna, UC82, yield 


\section{INTRODUCTION}

Tomato (Lycopersicon esculentum) production in Nigeria is constrained by many factors. These include shortage of improved varieties, disease and pest infestation, poor agronomic practices and poor postharvest handling. Although traditional agriculture was based on the use of low yielding varieties and low planting densities, attitudes moved in modern agriculture towards dense planting populations and use of varieties with high yield potential. Obtaining maximum yield depends on optimum planting density, cropping systems and the cultivar used (Dong et al., 2013). Plant spacing is the most important factor that affects yield and fruit quality of tomato (Tesfaye, 2008). Khan et al., (2002) also stated that plant population is one of the management practices that greatly influence tomato yield. The distance between row and plant depend on the production purpose, soil fertility and plant structure. According to Ibrahim (2012), plant density per unit area determines the optimal above the ground conditions that allow the plant to be affected by the growth factors, light, water, temperature, nutrition. These influence productivity and hence the final yield. Space is needed for weeding along and between rows, to create good air circulation and to allow each crop to grow to its determined size.

This study was therefore carried out to evaluate the growth and yield responses of three varieties of tomato (Lycopersicon esculentum) to plant spacing.

\section{MATERIALS AND METHODS}

\section{Description of Experimental Area}

The study was conducted during the dry cropping seasons of (October-February) 2015/16 and 2016/17 in the Experimental Farm of the Department of Crop Science, Faculty of Agriculture, University of Benin, Benin City, Nigeria. The location lies between latitude $6^{\circ} 14^{\prime} \mathrm{N}$ and $734^{\prime} \mathrm{N}$ and longitude $5^{\circ} 40^{\prime} \mathrm{E}$ and $6^{\circ} 43^{\prime} \mathrm{E}$. Meteorological data during the experimental period was obtained from Nigerian Institute for Oil Palm Research (NIFOR). The portion of land for the experiment had previously been cultivated with leafy 
vegetables but was left fallow for one year and was over grown with mainly spear grass (Imperata cylindrica) and sensitive plant (Mimosa pudica).

\section{Source of Seeds}

Tomato seeds of three varieties, Roma Savanna, UC 82 and Roma VF were obtained from National Institute for Horticulture and Research (NIHORT).

\section{Soil Sampling and Analysis}

Before planting and after harvest, composite soil samples were collected from a depth of $0-30 \mathrm{~cm}$ using soil auger, air-dried and were crushed to pass through a $2 \mathrm{~mm}$ sieve and packaged for routine soil physical and chemical analysis according to standard laboratory procedures. Soil pH was determined using a pH meter. Organic carbon was determined by (Walkley and Black, 1962) wet oxidation method as modified by Jackson (1969). Total nitrogen was obtained by macro Kjeldahl method as modified by Jackson (1969). Available P was extracted by Bray I method (Bray and Kurtz, 1945) and P was estimated by the blue colour method of Murphy and Riley (1962). Exchangeable K and Na were determined using flame photometer, and $\mathrm{Ca}$ and $\mathrm{Mg}$ using the Atomic Absorption Spectrophotometer.

\section{Treatments and Experimental Design}

The experiment was a factorial combination of $3 \times 3$ in randomized complete block design (RCBD) with nine treatments in three replications. The treatments used for the trial were three varieties of tomato (Roma savanna, UC 82 and Roma VF) and three spacing regimes. $(75 \mathrm{~cm} \times 40 \mathrm{~cm}, 75 \mathrm{~cm} \times 50 \mathrm{~cm}$ and $75 \mathrm{~cm} \times 60 \mathrm{~cm})$ which corresponded to $33,333,25,925$ and 22,222 plants ha- ${ }^{-1}$ respectively. Each replicate had nine plots for a total of 27 plots in this experiment. 


\section{Cultural Practices}

The land was cleared with the debris worked into the soil with a hoe. Beds for planting were prepared and tomato seeds were sown in the nursery. Plots were mulched to conserve soil moisture and suppress weeds. Two weeks before transplanting, the field was marked out and beds of $3 \mathrm{~m} \times 1.8 \mathrm{~m}$ were prepared with $20 \mathrm{t} /$ ha poultry manure as basal application applied thereafter, three weeks old tomato seedlings were transplanted to the field depending on the treatment and maintained till harvest.

\section{Sampling and Measurements}

Data collection commences four weeks after transplanting. Four plants were randomly selected from each plot and tagged for the purpose of collecting data. Vegetative growth, and yield components of tomato were evaluated. Vegetative growth parameters measured included plant height $(\mathrm{cm})$, number of leaves, stem diameter $(\mathrm{cm})$, leaf area $(\mathrm{cm})^{2}$ and number of branches while the yield components measured number of days to $50 \%$ flowering, number of flowers, number of fruits, fruit weight per plant $(\mathrm{g})$ and fruit yield (t/ha).

\section{Statistical Analysis}

The data obtained were subjected to statistical Analysis of Variance (ANOVA) using Statistical Analysis System (SAS) version 1998, following the model for factorial experiment in a randomized complete block design and differences among treatments means were separated using the Least Significant Difference (LSD) at $(p \leq 0.05)$.

\section{RESULTS}

The meteorological data during the experimental period showed that the rainfall was sparse throughout the experimental period with no rain in December and January, 2015/16 and in January, 2017 which necessitated the need for irrigation (Table 1). 
Table 1: Weather condition during the period of the experiment

\begin{tabular}{llllllll}
\hline Year & $\begin{array}{l}\text { Weather } \\
\text { condition }\end{array}$ & October & November & December & January & February & March \\
\hline $2015 / 16$ & Rainfall $(\mathrm{mm})$ & 247.80 & 62.80 & 0.00 & 0.00 & 126.10 & 80.45 \\
& $\begin{array}{l}\text { Temperature }\left({ }^{\circ} \mathrm{C}\right) \\
\text { 2016/17 }\end{array}$ & 25.36 & 27.40 & 26.75 & 26.05 & 25.75 & 24.70 \\
& $\begin{array}{l}\text { Relative humidity } \\
(\%)\end{array}$ & 78.95 & 74.1 & 63.65 & 53.35 & 69.90 & 72.3 \\
& $\begin{array}{l}\text { Rainfall }(\mathrm{mm}) \\
\quad 157.70\end{array}$ & 58.80 & 31.10 & 0.00 & 7.00 & 155.10 \\
& $\begin{array}{l}\text { Temperature }\left({ }^{\circ} \mathrm{C}\right) \\
\quad 39.00\end{array}$ & 33.60 & 33.60 & 34.90 & 34.70 & 33.50 \\
& $\begin{array}{l}\text { Relative humidity } \\
(\%)\end{array}$ & 83.00 & 75.1 & 61.80 & 44.30 & 48.20 & 66.3
\end{tabular}

\section{Source: Nigerian Institute for Oil Palm Research (NIFOR)}

In Table 2, the physical and chemical properties of the soil used for the experiment gave the textural class as sandy loam. The organic carbon $(0.40) \mathrm{g} \mathrm{g}^{-1}$, total nitrogen $(0.04) \%$, available phosphorus (3.33) $\mathrm{mg} / \mathrm{kg}$, were all below recommended critical levels of $0.15 \%$ $\mathrm{N}, 10-16 \mathrm{mg} / \mathrm{kg} \mathrm{P}$ and $0.34 \mathrm{cmol} / \mathrm{kg} \mathrm{K}$ for crop production. Hence the need for additional nutrient amendments to the soil. The effect of variety on plant height was significant ( $p \leq$ 0.05). Roma Savanna had the highest plant height though it was statistically same with the UC 82 variety while Roma VF variety had the lowest plant height (Table 3). Plant spacing increased plant height significantly as spacing decreased. The narrowest spacing of $75 \mathrm{~cm}$ x $40 \mathrm{~cm}$ produced significantly highest plant height. The number of leaves were significantly increased by the varieties used, Roma savanna produced significantly higher number of leaves (191.87) above Roma VF (147.64) while the narrower spacing of $75 \mathrm{~cm} x$ $40 \mathrm{~cm}$ and $75 \mathrm{~cm} \times 50 \mathrm{~cm}$ increased number of leaves (214.12 and 171.37 ) respectively above the wider spacing of which produced (132.61). The effect of variety on stem 
diameter was not significant but it ranged from $1.59 \mathrm{~cm}-2.85 \mathrm{~cm}$ for varieties and $1.66 \mathrm{~cm}$ - $3.01 \mathrm{~cm}$ for plant spacing (Table 3). However, the effect of variety was significant for the number of branches and leaf area and these followed a similar trend UC82, produced the least number of branches (12.51) and leaf area $\left(133.13 \mathrm{~cm}^{2}\right)$. Leaf area of tomato decreased with increase in spacing. The highest value $\left(145.94 \mathrm{~cm}^{2}\right)$ for leaf area was recorded for the narrowest spacing of $75 \mathrm{~cm} \times 40 \mathrm{~cm}$ while wider spacing of $75 \mathrm{~cm} \times 60 \mathrm{~cm}$ produced the least number of branches (11.26) and leaf area $\left(129.15 \mathrm{~cm}^{2}\right)$. There were significant differences among treatments for effect of varieties on number of days to $50 \%$ flowering. Roma savanna variety attained 50\% flowering (21.56) earlier than UC82 (28.00) and Roma VF (28.77). However, 50 \% flowering, number of flowers per plant and fruit yield (t/ha) decreased with increase in spacing (Table 4). The highest fruit yield (10.87 t/ha) was produced by Roma savanna followed by UC 82 ( 8.73 tha) and then Roma VF ( $8.28 \mathrm{t} / \mathrm{ha}$ ) which were statistically similar. The $75 \mathrm{~cm} \times 40 \mathrm{~cm}$ spacing produced the highest fruit yield (10.41 tha) but was statistically similar to $75 \mathrm{~cm} \times 50 \mathrm{~cm}$ spacing whose fruit yield was ( $9.76 \mathrm{t} / \mathrm{ha})$. The lowest fruit yield $(7.72 \mathrm{t} / \mathrm{ha})$ was produced by the widest spacing of $75 \mathrm{~cm}$ $\mathrm{x} 60 \mathrm{~cm}$. 
Table 2: Physical and chemical properties of the experimental soils before planting and after planting

\begin{tabular}{lll}
\hline Soil properties & $\begin{array}{l}\text { Before } \\
\text { Planting }\end{array}$ & $\begin{array}{l}\text { After } \\
\text { Planting }\end{array}$ \\
\hline $\mathrm{pH}\left(\mathrm{H}_{2} \mathrm{O}\right)$ & 5.16 & 5.23 \\
& & \\
Organic Matter $\left(\mathrm{g} 100 \mathrm{~g}^{-1}\right)$ & 0.40 & 0.79 \\
Total $\mathrm{N}\left(\mathrm{g}^{\left.100 \mathrm{~g}^{-1}\right)}\right.$ & 0.04 & 0.03 \\
Total P $\left(\mathrm{mg} \mathrm{kg}^{-1}\right)$ & 3.33 & 20.69 \\
$\mathrm{~K}\left(\mathrm{cmol} \mathrm{kg}^{-1}\right)$ & 0.14 & 0.16 \\
$\mathrm{Ca}\left(\mathrm{cmol} \mathrm{kg}^{-1}\right)$ & 1.30 & 1.20 \\
$\mathrm{Mg}\left(\mathrm{cmol} \mathrm{kg}^{-1}\right)$ & 0.70 & 0.60 \\
& & \\
Sand $(\%)$ & 66.43 & 66.87 \\
Clay $(\%)$ & 25.20 & 18.65 \\
Silt $(\%)$ & 8.00 & 8.12 \\
Textural class & \multicolumn{2}{c}{ Sandy loam } \\
\hline
\end{tabular}


TABLE 3: Effect of varieties and spacing on some vegetative growth components of tomato (Lycopersicon esculentum ) per plant

\begin{tabular}{|c|c|c|c|c|c|}
\hline Treatment & $\begin{array}{l}\text { Plant height } \\
\text { (cm) }\end{array}$ & No. of leaves & $\begin{array}{l}\text { No. of } \\
\text { branches }\end{array}$ & $\begin{array}{l}\text { Stem } \\
\text { diameter } \\
(\mathrm{cm})\end{array}$ & $\begin{array}{l}\text { Leaf area } \\
\left(\mathrm{cm}^{2}\right)\end{array}$ \\
\hline \multicolumn{6}{|l|}{ Varieties } \\
\hline $\begin{array}{l}\text { Roma } \\
\text { savanna }\end{array}$ & $57.24^{a}$ & $191.87^{a}$ & $12.17 \mathrm{ab}$ & $1.59 \mathrm{a}$ & $138.91^{\mathrm{ab}}$ \\
\hline UC82 & $56.68^{a}$ & $172.59^{a b}$ & $11.56^{b}$ & $2.85^{\mathrm{a}}$ & $133.13^{b}$ \\
\hline Roma VF & $51.11^{b}$ & $147.64^{b}$ & $12.51^{a}$ & $2.02^{\mathrm{a}}$ & $140.14^{a}$ \\
\hline Significance & * & * & * & N.S & * \\
\hline LSD & 3.52 & 49.36 & 0.83 & 1.87 & 6.42 \\
\hline \multicolumn{6}{|l|}{ Spacing(cm) } \\
\hline $75 \times 40$ & $59.89^{a}$ & $214.12^{\mathrm{a}}$ & $12.58^{a}$ & $3.01^{\mathrm{a}}$ & $145.94^{a}$ \\
\hline $75 \times 50$ & $55.32^{b}$ & $171.37 \mathrm{ab}$ & $12.39 a$ & $1.79^{a}$ & $137.08^{b}$ \\
\hline $75 \times 60$ & $49.83^{c}$ & $132.61^{b}$ & $11.26^{b}$ & $1.66^{a}$ & $129.15^{c}$ \\
\hline Significance & * & * & * & NS & * \\
\hline LSD & 3.52 & 49.36 & 0.83 & 1.87 & 6.42 \\
\hline
\end{tabular}


TABLE 4: Effects of varieties and spacing on yield and yield components of tomato (Lycopersicon esculentum )

\begin{tabular}{lccccc}
\hline Treatment & $\begin{array}{c}\text { No of days to } \\
\mathbf{5 0 \%} \\
\text { flowering }\end{array}$ & $\begin{array}{c}\text { No of } \\
\text { flowers per } \\
\text { plant }\end{array}$ & $\begin{array}{c}\text { No of fruit } \\
\text { per plant }\end{array}$ & $\begin{array}{c}\text { Fruit wt per } \\
\text { plant (g) }\end{array}$ & $\begin{array}{c}\text { Fruit } \\
\text { yield } \\
\text { (t/ha) }\end{array}$ \\
\hline $\begin{array}{l}\text { Varieties } \\
\text { Roma }\end{array}$ & $21.56^{\mathrm{b}}$ & $20.25^{\mathrm{a}}$ & $10.01^{\mathrm{a}}$ & $404.88^{\mathrm{a}}$ & $10.87^{\mathrm{a}}$ \\
savanna & & & & & \\
UC82 & $28.00^{\mathrm{a}}$ & $20.11^{\mathrm{a}}$ & $6.73^{\mathrm{b}}$ & $322.59^{\mathrm{b}}$ & $8.73^{\mathrm{b}}$ \\
Roma VF & $28.77^{\mathrm{a}}$ & $18.33^{\mathrm{a}}$ & $7.66^{\mathrm{b}}$ & $310.32^{\mathrm{b}}$ & $\begin{array}{c}8.28^{\mathrm{b}} \\
{ }^{*}\end{array}$ \\
Significance & ${ }^{*}$ & $\mathrm{NS}$ & ${ }^{*}$ & ${ }^{*}$ & \\
LSD & 1.28 & 3.11 & 1.06 & 60.78 & 1.64 \\
Spacing(cm) & & & & & \\
$75 \times 40$ & $28.22^{\mathrm{a}}$ & $23.44^{\mathrm{a}}$ & $8.17^{\mathrm{a}}$ & $324.63^{\mathrm{a}}$ & $10.41^{\mathrm{a}}$ \\
$75 \times 50$ & $26.22^{\mathrm{b}}$ & $20.39^{\mathrm{a}}$ & $7.98^{\mathrm{a}}$ & $383.24^{\mathrm{a}}$ & $9.76^{\mathrm{a}}$ \\
$75 \times 60$ & $23.89 \mathrm{c}$ & $14.85^{\mathrm{b}}$ & $8.14^{\mathrm{a}}$ & $329.93^{\mathrm{a}}$ & $7.72^{\mathrm{b}}$ \\
Significance & $*$ & $*$ & $\mathrm{NS}$ & $\mathrm{NS}$ & ${ }^{*}$ \\
LSD & 1.28 & 3.11 & 1.06 & 60.78 & 1.64 \\
\hline
\end{tabular}

Means followed by the same letter in a column are not significantly different at $5 \%$ level of probability.

* Significant at $5 \%$ level of probability, 


\section{DISCUSSION}

The soil of the experimental site gave the textural class as sandy loam. The organic carbon, total nitrogen, available phosphorus, were all below recommended critical levels of $0.15 \% \mathrm{~N}, 10-16 \mathrm{mg} / \mathrm{kg} \mathrm{P}$ and $0.34 \mathrm{cmol} / \mathrm{kg} \mathrm{K}$ for crop production (Aduayi et al; 2002). Fertilizer or manure application is required for optimum growth and yield of any crop in a nutrient deficient soil, hence the need for additional nutrient amendments to the soil. Previous findings revealed that tropical soils are usually deficient in one or more of the essential elements needed for crop growth (Adeoye and Agboola, 1985). The increase in plant height, number of leaves and most of the vegetative characters observed with the narrower spacing of $75 \mathrm{~cm} \times 40 \mathrm{~cm}$ and $75 \mathrm{~cm} \times 50 \mathrm{~cm}$ suggest that it could probably be the best spacings for these varieties of tomato plants. Plants under the closer spacings had adequate ground cover due to the tendency of plants to form canopy thereby conserving soil moisture, nutrients and regulating the soil temperature which could have resulted in a greater number of leaves and increase in plants height. The superiority observed in Roma savanna compared with the other two varieties in most of the yield and yield attributes is in accordance with the findings of (Law-Ogbomo and Egharevba, 2008) who reported that UC82 yielded low when compared with other varieties evaluated. The significant early flowering and subsequent highest fruit yield observed in Roma savanna is in agreement with the findings of Mehta and Asati (2008) and Sharma et al. (2009) who indicated that early flowering varieties would be beneficial for attaining higher yield of tomato. The decrease in the number of flowers per plant and in the fruit yield ( $t / h a$ ) observed with the widest spacing suggests that the widest spacing of $75 \mathrm{~cm} \mathrm{x}$ $60 \mathrm{~cm}$ would not be favourable and economical for these tomato varieties in this locality. The highest fruit yield obtained at the narrower spacing of $75 \mathrm{~cm} \times 40 \mathrm{~cm}$ could also be attributed to the higher number of plants per unit area. Consequently, producing a greater number of fruits and fruit yield per hectare. Wider spacing reduced yield due to total reduction in plants per hectare and consequently spacing is not fully utilized. These results are evidently in accordance with those of Khan et al., (2002) and Aliyu et al., (2008). 


\section{CONCLUSION AND RECOMMENDATION}

This study shows that early flowering varieties have a beneficial effect for attaining higher yield of tomato. It was also observed that Roma savanna was superior to the other varieties in terms of the yield attributes. Increase in plant spacing from $75 \mathrm{~cm} \times 40 \mathrm{~cm}$ to $75 \mathrm{~cm} \times 60 \mathrm{~cm}$ resulted in decrease in some vegetative characters and fruit yield per hectare of tomato plant. Highest fruit yield was recorded with $75 \mathrm{~cm} \times 40 \mathrm{~cm}$ though not statistically different from $75 \mathrm{~cm} \times 50 \mathrm{~cm}$ for most parameters measured. In conclusion, Roma savanna variety produces the highest fruit yield (t/ha) at either $75 \mathrm{~cm} \times 40 \mathrm{~cm}$ or $75 \mathrm{~cm} \times 50 \mathrm{~cm}$ plant spacing and therefore should be recommended to farmers in this locality.

\section{REFERENCES}

Adeoye, G.O. and Agboola, A.A. (1985). Critical levels for soil pH, available P, K, Zn and $\mathrm{Mn}$ and maize ear-leaf content of $\mathrm{P}, \mathrm{Cu}$ and $\mathrm{Mn}$ in sedimentary soils of SouthWestern Nigeria. Fertilizer Resources, 6: 65-71.

Aduayi E.A., Chude, V.O., Adebusuyi B.O., and Olayiwola, S.O. (2002). Fertilizer use and management practices for crops in Nigeria (3rd ed.). Federal Fertilizer Department, Federal Ministry of Agriculture and Rural Development, Abuja, P. 188.

Aliyu, U., Dikko, A.U., Magaji M.D. and Singh, A. (2008). Nitrogen and intra row spacing effect on onion (Allium cepa L.) Journal of Plant Science, 3: 188 - 193.

Bray, R.H. and Kurtz, L.T. (1945). Determination of total organic and available forms of $P$ in soils. Soil Science, 59: $39-45$.

Dong, H., Li, W., Tang, W., Li, Z., Zhang, D. and Niu, Y. (2013). Yield, quality and leaf senescence of cotton grown at varying planting dates and plant densities in the Yellow River Valley of China. Field Crops Resources, 98:106-115. 
Ibrahim, H.M. (2012). Response of Some Sunflower Hybrids to Different Levels of Plant Density. APCBEE Procedia 4:175-182.

Law-Ogbomo, K. and Egharevba, R.K.A. (2008). Effects of planting density and NPK fertilizer application on yield and yield components of tomato (Lycopersicum esculentum Mill) in a forest location. World Journal Agricultural Science, 5(2): $152-158$

Mehta, M. and Asati, B.S, (2008). "Genetic relationship of growth and development traits with fruit yield in tomato (Lycopersicon esculentum Mill)," Karnataka Journal of Agricultural Science, 21 (1), 92-96.

Murphy, J. and Riley, J.P (1962). Modified Single solution methods for determination of phosphorus in natural water. Analytical Chemistry Acta 27:31 -36.

Tesfaye, B., (2008). Response of tomato cultivars differing in growth habit to nitrogen and phosphorus fertilizers and spacing on vertisol in Ethiopia, Department of Plant Sciences, Ambo University College of Agriculture.

Jackson, M.L. (1969). Soil Chemical Analysis. Constable and Co Ltd, London, U.K. 132 pp.

Khan, H.M., Igbal, A., Ghaffoor and Waseem, K. (2002). Effect of various plant spacing and different level of fertilizers on the growth and yield of onion (Allium cepa $L$.) Journal of Biological Sciences 2: $545-547$.

Statistical Analysis System (SAS) (1998). SAS Users Guide Com. N.C. Statistical Analysis Institute, pp 256

Sharma, R. P., Datt, N. and Sharma P. K. (2009). Combined application of Nitrogen, Phosphorus; Potassium and Farm yard manure in Onion under High Hills, Dry 
Temperate conditions of North - Western Himalayas. Indian Journal of Agricultural Science 73: 4: 225 - 227.

Walkley, J. and Black, J.P. (1962). A critical examination of a rapid method for determining organic carbon in soils. Effects of variation in digestion conditions and of organic carbon constituents. Soil Science 63: $251-263$. 